\title{
Systematic literature review: opportunities and trends to the post-outbreak period of COVID-19
}

Barbara Tokarz¹, Eloiza Kohlbeck¹, Fernanda Hänsch Beuren', Alexandre Borges Fagundes', Delcio Pereira ${ }^{1}$

${ }^{1}$ Santa Catarina State University - UDESC, São Bento do Sul, SC, Brazil.

How to cite: Tokarz, B., Kohlbeck, E., Beuren, F.H. et al. (2021), "Systematic literature review: opportunities and trends to the post-outbreak period of COVID-19", Brazilian Journal of Operations \& Production Management, Vol. 18, No. 2, e20211146. https://doi.org/10.14488/BJOPM.2021.030

\section{ABSTRACT}

Goal: The aim of this study is to conduct a systematic literature review to identify opportunities to minimize Covid-19 impacts on businesses.

Design / Methodology / Approach: The methodology used corresponds to a literature systematic review, covering bibliometric and content analysis. For this purpose, the Preferred Reporting Items for Systematic Reviews and Meta-Analyses (PRISMA) was employed in the literature search. In total, 98 papers were selected to compose the bibliometric analysis, of which 14 are within the scope of the investigation (content analysis).

Results: Bibliometric results present a grouping of keywords, authors' co-citation network, geographic distribution of publications and main journals. In the content analysis, trends for postpandemic economy are pointed out, unveiling guidelines and opportunities to ensure the resilience of business proposals.

Limitations of the investigation: The conclusions present limitations inherent to literature review papers, where filters are used to limit the search. In this work, the research was restricted to articles, published between 2015 and 2020 and written in English.

Practical implications: This article proposes perspectives to react in a resilient way in the postPandemic period of Covid-19, in order to guarantee the permanence and competitiveness of the companies in the market.

Originality / Value: Product-Service Systems and Circular Economy were found to be related to the trends and opportunities identified for the short-future economy.

Keywords: Covid-19; Systematic Literature Review; Circular Economy; Product-Service System; Business Opportunity.

\section{INTRODUCTION}

The coronavirus outbreak identified in Wuhan, Hubei province, China, in December 2019 (Zhang et al., 2020a) spread fast through the world, revealing challenges in healthcare, economic, environmental and societal fields (Chakraborty and Maity, 2020). In attempt to balance medical needs and resources availability, an unprecedented tension arose (Ramakrishna et al., 2020). Along with it, a need for a new perspective in the offer of products and services, an intertwined supply chain with suppliers, stakeholders and market demands (Ivanov and Dolgui, 2020).

Financial support: None.

Conflict of interest: The authors have no conflict of interest to declare.

Corresponding author: fernanda.beuren@udesc.br

Received: 12 Jan 2021.

Approved: 17 Mar 2021.

Editor: Syed Abdul Rehman Khan. 
In a post-outbreak period, hard work will be necessary to rightfully implement new economic models, with perspective changes for the supply and production system (Sarkis et al., et al., 2020). New consuming models should be promoted (Lu et al., 2020), integrating supply chain with Circular Economy and other fields (Ivanov and Dolgui, 2020). Business models such as Product-Service Systems (PSS), commonly seen as models capable of guiding society into a Circular Economy (Halstenberg et al., 2019; Hankammer et al., 2019; Pieroni, et al., 2019), represent an opportunity to establish a synergic relationship between the environment and economic growth (Jia et al., 2020).

Some tendencies emerge as ways of minimizing Covid-19 (the disease caused by the new coronavirus) repercussions. Incorporating information and communication technologies is one of them, which allows, at the same time, social connection (an impression of proximity) and a small exposure (social distancing) for vulnerable and high-risk individuals (Király et al., 2020). It is important for companies to follow these trends, in order to maintain competitiveness amid a global health crisis, acting in a resilient, enterprising and strategically agile way (Liu et al., 2020).

Thus, the need to promote sustainable supply chain management arises (Khan et al., 2021). Considering the Covid-19 pandemic context, Yu and Khan (2021) conducted a study focused on the food sector and highlighted that investment in green products stimulates supply chain development. From these considerations, a research question is established: "How can the supply chain act with resilience and environmental awareness in the face of the covid19 outbreak?". Aiming at answering this question, the goal of this paper is to conduct a systematic literature review to identify opportunities to minimize Covid-19 impacts on businesses, identifying business trends.

The next section of this paper presents a theoretical background on the concepts discussed. The third section describes the research methods. The fourth section presents the results and discussions of the bibliometric and content analysis. Finally, the last section presents some conclusions and research perspectives.

\section{LITERATURE REVIEW}

\section{Covid-19 and Circular Economy}

The Covid-19 pandemic not only caused numerous deaths, but also triggered impacts on the world economy on a scale not seen since the Great Depression (Laing, 2020). To ensure the survival of supply chains, it is necessary to consider an interconnected network between suppliers, focal companies and market demands, integrating areas such as the Circular Economy (Ivanov and Dolgui, 2020).

The long-term recovery from the impacts caused by the pandemic will be influenced by the transformation of the current linear production model, which favors high resource consumption, into a model based on the principles of the Circular Economy (Prideaux et al., 2020). The most relevant definition of Circular Economy was elaborated by the Ellen MacArthur Foudation (Geissdoerfer et al., 2017), and emphasizes its capacity to redefine economic growth, prioritizing financial advantages for companies (Geissdoerfer et al., 2017) valuing benefits for all society, based on the regeneration of natural systems, the maintenance of products and materials in use, and the projection of waste and pollution (Ellen MacArthur Foundation, 2017).

Thus, it is essential to ensure safe waste management during the Covid-19 pandemic, in particular contaminated masks, gloves, medications and medical utensils, which should be treated as hazardous waste and disposed of separately (Zambrano-Monserrate et al., 2020). To meet the needs that emerge from the Coronavirus outbreak and also ensure the sustainability of resources, the demand for evidence-based research and the need to invest in smart innovations and services, promoting eco-innovation arises (Rowan and Laffey, 2020).

The Circular Economy emerges as a strategy capable of aligning social equity, economic welfare and environmental balance (Secco et al., 2020), where collaborative consumption has 
attracted attention due to the emergence of new business models based on shared economy (Retamal, 2019). In this context, the Product Service System (PSS) corresponds to a model capable of leading society to a Circular Economy (Halstenberg et al., 2019; Hankammer et al., 2019; Pieroni et al., 2019).

\section{Covid-19 and Product-Service System}

The Product-Service System corresponds to a specific type of business model composed of products, services, network of actors and infrastructure (Mont, 2002), capable of developing an indispensable "resource revolution" (Tukker, 2015) and accelerating the transition from patterns of value creation to ensure the delivery of solutions to the customer, integrating products and services (Zhang et al., 2020b). The PSS should be planned at the systemic level (Fernandes et al., 2020), integrating economic, social and environmental aspects (Annarelli et al., 2016). The Product-Service Systems approach represents an opportunity, especially for countries with emerging or developing economies (Retamal, 2019), and in the post-pandemic period, it will be necessary to resume production, promoting new types of consumption (Lu et al., 2020).

In the midst of the Covid-19 outbreak, supply chain shortages correspond to a growing global concern (Rowan and Laffey, 2020). It is necessary to ensure the supply of goods and services to society and ensure long-term survival in all sectors of industry (Ivanov and Dolgui, 2020). Through the PSS, it is possible to meet the needs of consumers through the customization of products and services, in addition to providing sustainability to consumption and production (Yu et al., 2008).

The Product-Service System can be understood as an opportunity for innovation towards sustainability, capable of significantly reducing the environmental impacts of traditional production and consumption systems (Vezzoli et al., 2018). For a successful recovery from the Covid-19 outbreak, sustainability-based measures must be considered (Ryan et al., 2020). In this context, entrepreneurship can provide creative solutions, aiming at resilience and agility to overcome the crisis caused by the pandemic (Liu et al., 2020).

\section{RESEARCH METHODS}

The research followed four different stages, that are presented in Figure 1. On the first stage, a research problem was defined. The Introduction section of this paper contextualizes the research question and its definition.

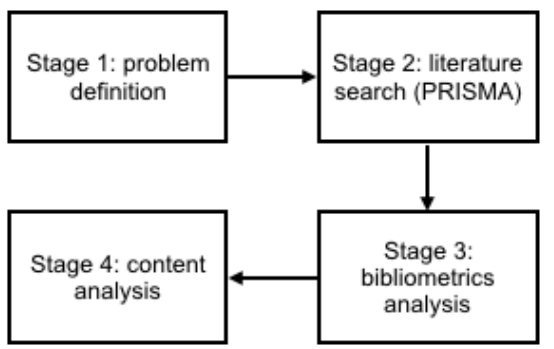

Figure 1. Stages of the research. Source: The authors themselves.

\section{Stage 2: literature search}

In order to address the research question and the defined goal, Stage 2 encompassed a literature search through the employment of the Preferred Reporting Items for Systematic Reviews and Meta-Analyses (PRISMA) (Figure 2). The method comprises four phases:
a. Record identification;
b. Record screening;
c. Eligibility assessment;
d. Inclusion of studies (Moher et al., 2009). 
For record identification, literature search was conducted in Scopus and Web of Science databases - considered the widest ones (Chadegani et al., 2013). A combination of keywords was employed: "corona virus" OR "covid 19" was combined with "supply chain" OR sustainability OR "sustainable development" OR "sustainable development goals" OR "service design" OR (product OR service). This first phase encountered 1391 papers.

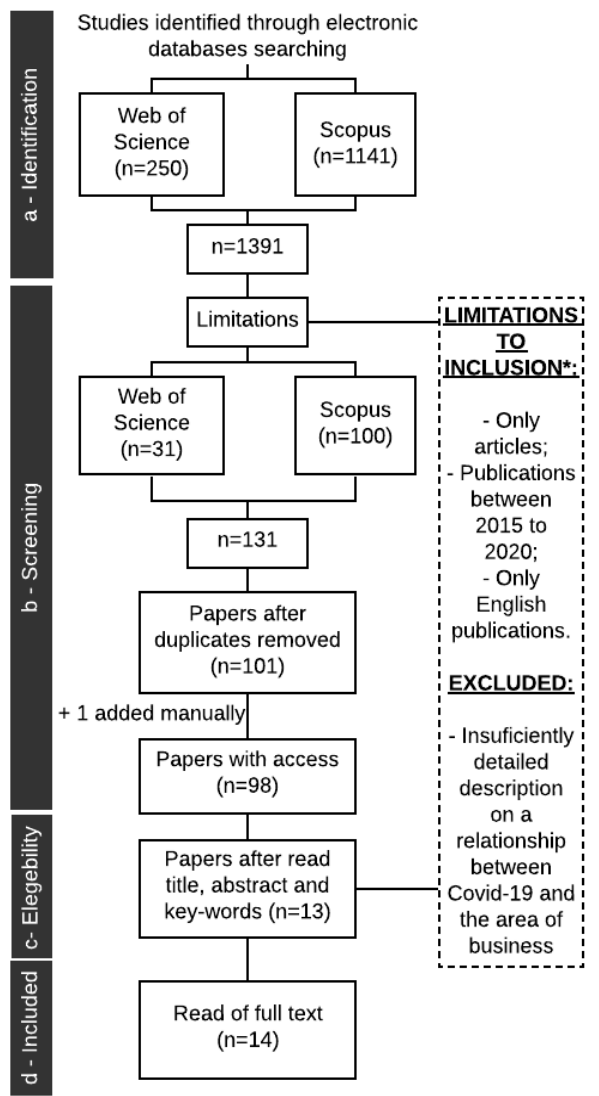

Figure 2. PRISMA application and research parameters. Source: The authors themselves.

For phase (b), record screening, research filters were employed, as exposed in Figure 2. The publishing dates were limited to the last 5 years (2015 to 2020, when the search was performed), due to the novelty of the topic. Subject filters were also employed for the keyword combination ("corona virus" OR "covid 19") AND (product OR service), due to the great number of documents initially tracked. For Scopus search, the subject filters Engineering, Environmental Science and Business, Management and Accounting were employed. For the Web of Science search, the subject filters Ecology, Engineering Industrial, Engineering Manufacturing, Management, Economics, Operations Research, Management Science and Multidisciplinary Sciences were employed.

After filter application and duplicates removal (phase 2), the number of papers was 101. We were not able to access four of these paper's full text, and one paper was manually added, so the library was formed with 98 documents, sample that made up the bilbliometric analysis.

For phases (c) and (d) of PRISMA, paper's titles, keywords and abstracts were read, gathering those that seemed to present the greatest contributions to this research. Fourteen papers were selected to be deeply analyzed on Stage 4 of this research. These results lead to the execution of the third and fourth Stages for the research, as presented in Figure 1.

\section{Stage 3: bibliometric analyses}

Stage 3 comprehended bibliometric analyses, using the 98 (97 gathered + 1 manually inserted) selected references, where keywords grouping, geographical distribution of publications, authors' co-citation network and journals with the highest number of publications are presented, respectively. 
Aiming at mapping the most explored search themes by grouping keywords, the VOSviewer ${ }^{\circledR}$ software was used, a free tool that allows creating graphs to visualize bibliometric data (Wong, 2018). The type of analysis was "co-occurence", the unit of analysis "all Keywords" and the method of counting "full counting", using the same weight for the connection links. To perform the analysis of co-citations of authors, VOSviewer ${ }^{\circledR}$ software was also employed, where the type of analysis was "co-citation", the unit was "cited authors", the method of counting "full counting" and, the minimum number of citations established was 10 for each author.

VOSviewer ${ }^{\circledR}$ limits the use for one database only. Therefore, Scopus database was used because it presented the highest number of results (Benachio et al., 2020). For reference management, Mendeley ${ }^{\circledR}$ software was employed in all stages of the research.

\section{Stage 4: content analysis}

Stage 4 of the research comprised a content analysis of the 14 selected papers. The papers were initially read, their goals and main contributions were congregated (Tokarz et al., 2020) and presented in the results and discussions section (see Table 1).

Most of the papers presented a state of the art and/or trends for a post-Pandemic period within similar topics, which were important to guide the analyses. The topics are economic impacts and trends; changes in supply chain operations; 3D printing opportunities; technology to manage information; and other trends for the post-pandemic economy.

\section{RESULTS AND DISCUSSION}

The first section of this chapter presents a descriptive analysis of the bibliometric results obtained with the 98 articles included in this literature review. The following sections present an analysis of the content of the 14 selected papers.

\section{Stage 3: bibliometric analysis}

In order to map the most explored research topics, a keyword clustering network was created (see Figure 3). Among the most used keywords, "Covid-19", with 55 occurrences; followed by "pandemic", with 32 occurrences. The use of terms with the same meaning is observed, such as "human" and "humans", or "coronavirus infection" and "coronavirus infections", highlighting the importance of the use of truncation elements in database searches, which allows the recovery of all the expansions a word can present.

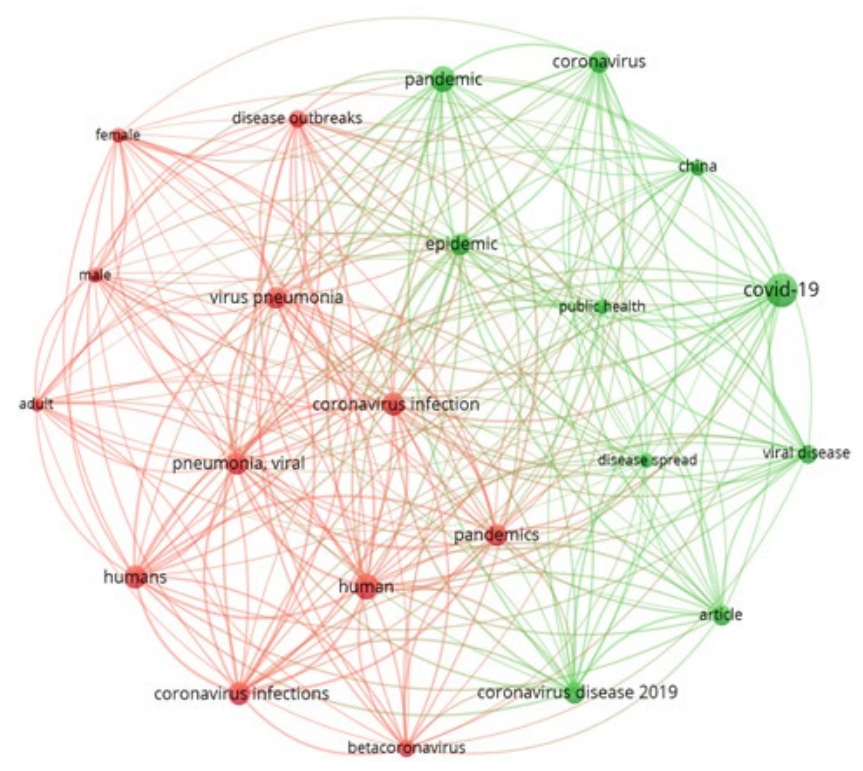

Figure 3. Keyword grouping. Source: The authors themselves. 
According to van Eck and Waltman (2014) the nodes and edges of the bibliometric network in Figure 3 indicate the correlation and strength of the connection between keywords, so, the larger the node, the greater the correlation. Figure 3 presented the formation of two clusters, with a high level of interrelationship, where is observed that most of keywords are related to health areas, with few links with the terms used in this research: "supply chain", "sustainability", "sustainable development", "sustainable development goals", "service design" and "product" OR "service".

Among the keywords not related to the medical field, "human" stands out, with 31 occurrences and "China", with 13 occurrences, due to the origin of Covid-19 in Wuhan, Hubei province (China), in December 2019 (Li et al., 2020b). The pandemic affected several sectors of the world economy, mainly tourism (World Tourism Organization, 2020), which granted search results with a large number of researches on this problem, with China being among the countries with the largest number of scientific publications.

The United States and China are the countries with the largest number of publications in this analysis, since together they present $33.67 \%$ of the total number of articles examined. A global involvement in research related to the Covid-19 pandemic is observed, especially in North America, as the United States presents 20 publications and Canada nine. Asia (China, Malaysia and India) also stands out for presenting a large number of scientific productions (24.49\% of the total number of articles).

The VOSviewer ${ }^{\circledR}$ software was used to analyze co-citations among the authors of the articles selected for this research. Figure 4 presents the formation of three groupings, assembling a bibliometric network composed of 23 nodes.

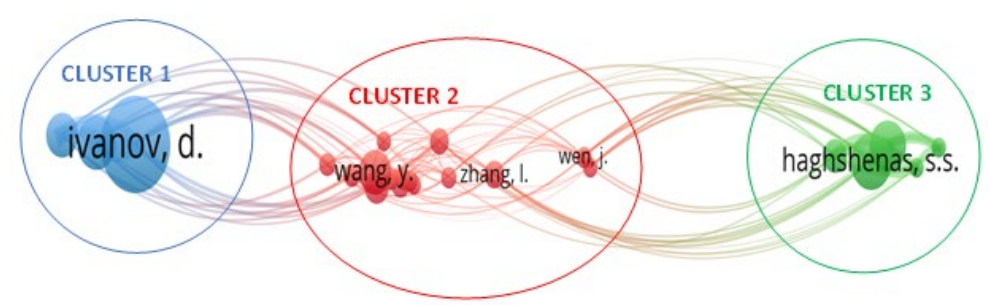

Figure 4. Authors' co-citation network. Source: The authors themselves.

The first cluster has the most cited author of the whole analysis, Ivanov, D., presenting 48 citations in this bibliometric network, where it is highlighted the publication in the journal Transportation Research Part E: Logistics and Transportation Review, in March 2020: "Predicting the impacts of epidemic outbreaks on global supply chains: A simulation-based analysis on the coronavirus outbreak (COVID-19/SARS-CoV-2) case".

The most cited authors in cluster 2 are Wang, Y., with 22 citations and Zhang, L., with 14. In the third cluster, the Iranian author Haghshenas, S. S. stands out as the second author with the largest number of publications (28) in this network of co-citation. The author has two publications related to COVID-19 in the SCOPUS database, both analyzing the challenges of the pandemic in sustainable development.

Considering the sources of the analyzed papers (see Figure 5), 18.37\% were published in the International Journal of Environmental Research and Public Health. The large number of publications in this journal can be justified by the launch of six special editions on Covid-19, which are in progress. The articles have been published in 60 different journals, most of which have as scope areas of health and sustainable development.

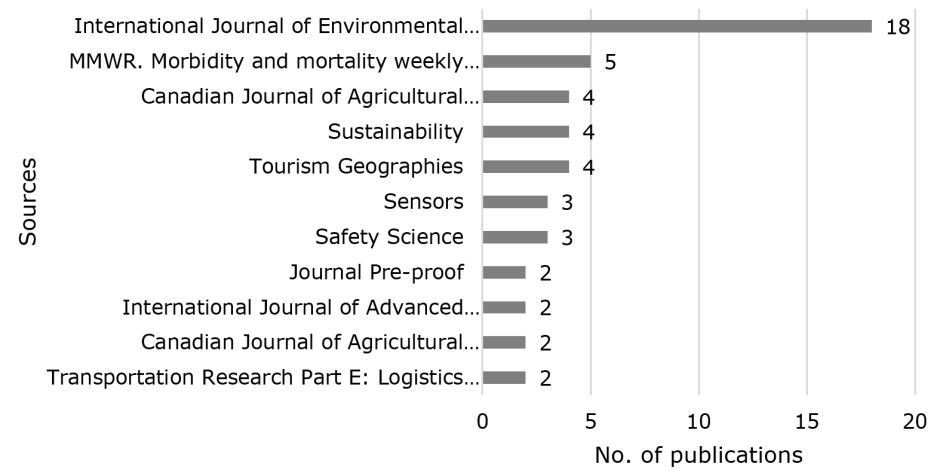

Figure 5. Main journals. Source: The authors themselves. 


\section{Stage 4: content analysis}

The fourth Stage of this research encompassed a content analysis for 14 papers selected during Stage 2, PRISMA application. A Table was assembled to organize papers' goals and main contributions (see Table 1).

Table 1. Papers contributions

\begin{tabular}{|c|c|c|c|}
\hline Ind. & Paper goal & Paper main contributions & Reference \\
\hline 1 & $\begin{array}{l}\text { Explore the effects of Covid-19 } \\
\text { pandemic on global economy. }\end{array}$ & $\begin{array}{l}\text { The authors present a detailed panorama of the } \\
\text { global economy facing the pandemic and point out } \\
\text { opportunities on a post-pandemic era. }\end{array}$ & $\begin{array}{l}\text { (Açikgöz and } \\
\text { Günay, 2020) }\end{array}$ \\
\hline 2 & $\begin{array}{l}\text { Report ideas, technology and some } \\
\text { health concerns on 'learn through } \\
\text { doing' initiatives to manufacture } \\
\text { PPEs in the U.S. }\end{array}$ & $\begin{array}{l}\text { Explores on the importance of collaboration between } \\
\text { the interested ones to achieve results. }\end{array}$ & $\begin{array}{l}\text { (Armani et al., } \\
\text { 2020) }\end{array}$ \\
\hline 3 & $\begin{array}{l}\text { Show how Covid-19 affects the } \\
\text { transportation services and the } \\
\text { agricultural supply chain in Canada. }\end{array}$ & $\begin{array}{l}\text { The author points behavioral and economic } \\
\text { tendencies to a post-pandemic period. }\end{array}$ & (Gray, 2020) \\
\hline 4 & $\begin{array}{l}\text { Explore on the context and } \\
\text { opportunities to develop } \\
\text { sustainable modes of production } \\
\text { triggered by the new coronavirus } \\
\text { outbreak. }\end{array}$ & $\begin{array}{c}\text { The authors present different approaches for the } \\
\text { update of production systems toward more } \\
\text { sustainable supply chains, highlighting that the } \\
\text { pandemic could be a trigger to the necessary changes } \\
\text { in the business sector. }\end{array}$ & $\begin{array}{l}\text { (Sarkis et al., } \\
\text { 2020) }\end{array}$ \\
\hline 5 & $\begin{array}{l}\text { Show how simulation-based } \\
\text { methods can predict and analyze } \\
\text { the impacts of epidemic outbreaks. }\end{array}$ & $\begin{array}{c}\text { The paper presents a simulation case study of } \\
\text { product distribution worldwide, and the impacts of } \\
\text { the pandemic's containment measures over a supply } \\
\text { chain. }\end{array}$ & (Ivanov, 2020) \\
\hline 6 & $\begin{array}{l}\text { Conceptualize a novel decision- } \\
\text { making environment for supply } \\
\text { chains }\end{array}$ & $\begin{array}{l}\text { Concept of a decision-making environment based on } \\
\text { the intertwined supply network and feasibility to } \\
\text { ensure survival to the Covid-19 outbreak. }\end{array}$ & $\begin{array}{l}\text { (Ivanov and } \\
\text { Dolgui, 2020) }\end{array}$ \\
\hline 7 & $\begin{array}{l}\text { Explain the implications of } \\
\text { resilience, strategic agility and } \\
\text { entrepreneurship in the context of } \\
\text { fighting Covid-19, focused on } \\
\text { China, South Korea and Singapore. }\end{array}$ & $\begin{array}{c}\text { The authors comment that despite its negative } \\
\text { impacts, the Covid-19 outbreak presents unique } \\
\text { opportunities for entrepreneurs to demonstrate } \\
\text { creative interruptions for the benefit of individuals, } \\
\text { organizations and society. }\end{array}$ & (Liu et al., 2020) \\
\hline 8 & $\begin{array}{l}\text { Conduct interviews and surveys in } \\
\text { small and medium-sized Chinese } \\
\text { companies (SME) to analyze the } \\
\text { impacts of Covid-19. }\end{array}$ & $\begin{array}{l}\text { The authors point the pandemic as a huge challenge } \\
\text { for the survival of SMEs, but declare the Chinese } \\
\text { government is intervening with a series of measures } \\
\text { to revitalize the economy. }\end{array}$ & (Lu et al., 2020) \\
\hline 9 & $\begin{array}{l}\text { Analyze how the pandemic will } \\
\text { affect the achievement of } \\
\text { Sustainable Development Goals. }\end{array}$ & $\begin{array}{l}\text { The article comments on the need for countries to } \\
\text { strengthen their health care and focus on the most } \\
\text { vulnerable amid the Covid-19 pandemic. }\end{array}$ & (Thornton, 2020) \\
\hline 10 & $\begin{array}{l}\text { Better understand socially } \\
\text { responsible consumer behavior } \\
\text { (SRCB). }\end{array}$ & $\begin{array}{l}\text { The authors present the state of the art on SRCB, } \\
\text { associating the main areas addressed: corporate } \\
\text { social responsibility, consumer attitude and social } \\
\text { and sustainable consumer behavior. }\end{array}$ & $\begin{array}{l}\text { (Nova- } \\
\text { Reyes et al., } \\
\text { 2020) }\end{array}$ \\
\hline 11 & $\begin{array}{l}\text { Describe solutions and challenges } \\
\text { to address the shortage of PPE in } \\
\text { an Irish regional hospital. }\end{array}$ & $\begin{array}{l}\text { It suggests improvements in communication lines to } \\
\text { improve inventory management and PPE production } \\
\text { through customized production and development of } \\
\text { web pages and mobile applications. }\end{array}$ & $\begin{array}{l}\text { (Rowan and } \\
\text { Laffey, 2020) }\end{array}$ \\
\hline 12 & $\begin{array}{l}\text { Propose a framework, based on } \\
\text { the human needs cited by Maslow, } \\
\text { to identify the best way forward } \\
\text { amid the Covid-19 pandemic. }\end{array}$ & $\begin{array}{c}\text { The authors propose a framework to bring about } \\
\text { stabilization, sustainability and job security in order to } \\
\text { protect the most vulnerable to Covid- } 19 \text {. }\end{array}$ & $\begin{array}{l}\text { (Ryan et al., } \\
\text { 2020) }\end{array}$ \\
\hline 13 & $\begin{array}{l}\text { Present the difficulties the tourism } \\
\text { sector faces as results of } \\
\text { pandemics, such as Covid-19. }\end{array}$ & $\begin{array}{l}\text { The authors present some changes that will be seen } \\
\text { in the tourism sector after the pandemic, as well as } \\
\text { actions that could be taken by different stakeholders } \\
\text { in the area. }\end{array}$ & (Hall et al., 2020) \\
\hline 14 & $\begin{array}{l}\text { Explore the effects of Covid-19 } \\
\text { pandemic on the Canadian } \\
\text { processed food market. }\end{array}$ & $\begin{array}{l}\text { The food supply chain is highly affected by Covid-19 } \\
\text { pandemic, showing the need for it to be resilient. The } \\
\text { author highlights that the effects of the pandemic will } \\
\text { linger over the food supply chain for a while. }\end{array}$ & (Hailu, 2020) \\
\hline
\end{tabular}

Source: The authors themselves. 
The papers identified different impacts (e.g. Gray, 2020), possible points of change triggered by the Covid-19 outbreak (e.g. Sarkis et al., 2020), some tendencies and opportunities to minimize Covid-19 effects on businesses (e.g. Açikgöz and Günay, 2020).

The outbreak will occasion changes in global economic and social activities (Açikgöz and Günay, 2020). Some of them are already emerging (as for 2020, when the paper was written) as described by Açikgöz and Günay (2020) and grey literature.

These changes open space for new business models to emerge, or even those which are not new, but haven't yet reached a high level of recognition. Underlining Sarkis et al. (2020)'s proposition of more sustainable business models for a post-pandemic economy, two concepts can be emphasized: Circular Economy and Product-Service Systems. As explored in Literature Review Section, Product-Service Systems allow the provision of customized and dematerialized offers to customers (Yang et al., 2009; Beuren et al., 2013), while assuring circular principles (Guzzo et al., 2019), and presenting benefits to both the environment and society (Vezzoli et al., 2018).

\section{Economic impacts and trends}

Declaring a pandemic is not only a health issue, but it brings out economic, political and social consequences as well (Açikgöz and Günay, 2020). The spreading of the Covid-19 outbreak has been causing major economic effects all around the world (Liu et al., 2020). Most of them are already being evidenced, such as changes in production and consumption, unemployment (Açikgöz and Günay, 2020) and great reduction in activities that affect not only its direct stakeholders, but others downstream the supply chain (Gray, 2020; Lu et al., 2020).

One of the major problems identified for small and medium enterprises (SMEs) during the pandemic is uncertainty (Lu et al., 2020). SMEs don't hold big cash flows, and a study by Lu et al. (2020) with 4807 SMEs in China, showed that $60 \%$ of the enterprises would not survive three months under the current economic conditions. The earlier the SMEs activities can be resumed, the greater are their chances of survival (Ivanov, 2020; Lu et al., 2020). However, stopping the spread of the virus and resuming economic activities are two situations separated by a thin line (Liu et al., 2020; Lu et al., 2020).

For multinational enterprises (MNEs), the consequences are not the same as for SMEs. China has a key role in supply chains. Disruption effects in China echoes around the world (Açikgöz and Günay, 2020), and uncertainty in the country is harmful for others (Liu et al., 2020). This is the reason why MNEs are starting to relocate their strategic operations and value chain activities to optimal locations - in many cases, out of China (Liu et al., 2020). This relocation allows companies to benefit from local advantages and a global production scale (Liu et al., 2020).

Açikgöz and Günay (2020) predicted two possible economic outcomes to the Covid-19 outbreak. As expected, none of them are great. Sarkis et al. $(2020$, p. 2) highlight the opportunity the pandemic is opening to change the modes of production and consumption, by affirming that "[...] we should not allow the macroeconomic system, global supply chains, and international trade relations as we have known them to revert to 'normal' ". People are already experiencing changes in social life (Açikgöz and Günay, 2020), and this is an opportunity to start changes in other spheres.

As an example, South Korea's government and private businesses both predicted in- and post-pandemic growth for specific sectors. The outbreak is an opportunity for companies to enhance their reputations, developing corporate social responsibility. Resilience, strategic agility and entrepreneurship will play key roles in capturing value from opportunities, as strategic agility is crucial for companies to deal with social changes, and entrepreneurship allows the use of knowledge in creative solutions (Liu et al., 2020).

\section{Changes to supply chain operations}

Supply chains were significantly impacted by the coronavirus outbreak. People's sense of insecurity had an impact on market demand (Lu et al., 2020). Face-to-face services were badly affected, and so was the tourism sector. Businesses downstream the supply chain suffered 
losses by the closing of accommodation services, entertainment and cultural activities (Lu et al., 2020). Agricultural producers lost revenues for not selling to hotels (Lu et al., 2020) and schools (Gray, 2020). "A slight move in one section of the supply chain could severely affect the situation as a whole" (Lu et al., 2020, p. 13).

Ivanov (2020) presented a simulation model of a multistage supply chain affected by the Covid-19 outbreak. The network in the model involved five different products with customers spread around the world. The suppliers and factories were based in China, and distribution centers (DCs) were located in Europe, North and South America. Transportation time from China to DCs followed an average of thirty days, and from DCs to customers delivery took 4-9 days.

The author simulated different scenarios, evaluating the impact of the epidemic outbreak on supply chain performance. The parameters variations studied were epidemic durations and location of supply chain disruptions: supplier-factory; supplier-factory and distribution centers; or supplier-factory, distribution centers and markets (Ivanov, 2020).

The research concluded that supply chain performance depends on the scale of disruption propagation, i.e., how long it took for the coronavirus effects to reach not only the supplier-factory zone, but also distribution centers and markets. Other factors that were found to affect supply chain performance were the moments in time and how many times a facility would open and close during the outbreak (Ivanov, 2020).

Ivanov also developed a study in partnership with Dolgui (Ivanov and Dolgui, 2020), where the authors propose an interconnected supply network (ISN). Lu et al. (2020) reinforce this situation by commenting on the need to interconnect industrial chains, intensifying the link between production and sales in order to ensure resilience in resuming production at all levels of the industrial chain.

In view of the Covid-19 outbreak, Ivanov and Dolgui (2020) conceptualize a decision-making environment on the viability of an interconnected supply network (ISN), which interrelates suppliers, local firms and market demands (customers). The network introduces a new perspective to the supply chain and aims to guarantee the supply of products and services (e.g. food, mobility and communication) and to ensure the long-term survival of companies.

Therefore, authors (Açikgöz and Günay, 2020; Liu et al., 2020) have suggested changes within supply chain mechanisms to a post-pandemic economy. Transparency and micro-level supply chains are highlighted (Liu et al., 2020; Shokrani et al., 2020). Liu et al. (2020) underlines that Covid-19 has fastened two powerful trends for the future: the disassociation of supply chains from China and a strategic relocation of manufacturing operations.

While analyzing Ivanov's (2020) simulation results, it could be noted that supply chain disruptions and decrease in production and consumption didn't happen all at the same time, but sequentially as the virus spread around the world. Authors (Liu et al., 2020) have stated that the coronavirus outbreak caused disruptions in global supply chains, suggesting that local ones may have been less affected. Thus, the damage to supply chains - as the one modeled by Ivanov (2020) - could be smaller or less enduring if its actors were located in a more concentrated geographical area.

The strategy of building a business network of actors locally is a sustainable one, as it promotes local economy, generating jobs and improving quality of life (Vezzoli et al., 2018). This approach corroborates with Sarkis et al.'s (2020) statement that Covid-19 outbreak should be a trigger to change supply chain operations into more sustainable modes of production. Product-Service Systems are recognized as “[...] promising approaches to enhance the sustainability performance of traditional product systems" (Kjaer et al., 2019, p. 24), which presents it as an opportunity for short-future businesses.

\section{D printing opportunities}

During the Covid-19 pandemic, groups of 'learn through doing' in the United States started using 3D printers to build Personal Protective Equipment to health workers, with a special approval from the Food and Drug Administration (FDA) (Armani et al., 2020). Even 
though additive manufacturing techniques, such as 3D printing, were already being promoted before the pandemic (Calignano et al., 2017), authors (Armani et al., 2020; Cox and Koepsell, 2020; lyengar et al., 2020) suggest this will take place in short-future businesses, due to the enabled speed of production.

The 3D printing technique is also recommended as a possible way to postpone premature obsolescence, by being employed in the replacement of parts for fashion or malfunction reasons (Sarkis et al., 2020). The use of recovered plastics or metals as raw materials for the printers is proposed by Sarkis et al. (2020), who also indicates the repair business opportunity to small and local enterprises.

The case described by Armani et al. (2020) expresses the possibility of collaboration between interested parts on achieving a specific result. Even though collaboration between big enterprises is already commonly known as advantageous (Lin et al., 2012), the employment of small enterprises or entrepreneurs is not widespread as much (Gray, 2020). This co-operation is a direction toward Circular Economy (Schröder et al., 2019), presented as a sustainable system - mainly economic and environmentally beneficial (Geissdoerfer et al., 2017).

Furthermore, Sarkis et al. (2020) proposal to use recovered plastics and metals as raw materials for the printers is environmentally favorable. The contributions of providing small and local enterprises with new business opportunities are twofold. For once, it is a way of helping them recover from the economic impacts caused by the Covid-19 outbreak, and secondly, it relates to Product-Service Systems and the social pillar of sustainability (Vezzoli et al., 2018).

\section{Technology to manage information}

While discussing the circumstances involving health systems during the Covid-19 outbreak, World Health Organization (2021) pointed "the need for stronger data and health information systems", arguing that the pandemic confirmed this need by revealing flaws in the current models of health systems and their co-dependent systems. This opens space to proposals like the one from Celesti et al. (2020), to use Internet of Things to connect doctors, nurses and technicians around the world in shared tele laboratories for the performance of Covid-19 tests.

Liu et al. (2020) predicted a growth in non-contact industries, e.g., "telecommunication, online education, and remote support solutions". Açikgöz and Günay (2020) and Sarkis et al. (2020) also suggested the use of technologies to manage information in the short-coming future, especially in the health care field (Leite et al., 2020). Celesti et al.'s (2020) proposal can be classified as a telemedicine project. Other telemedicine practices were discussed by Leite et al. (2020) and Smith et al. (2020), while Giudice et al. (2020) explores the viability of teledentistry to monitor post-op patients, reducing costs and limiting human contact during the Covid-19 outbreak.

The initiative by Giudice et al. (2020) brings about an important aspect regarding the environmental effects of telemedicine practices. A study by Li et al. (2020a) exhibited the improvement of air quality in China during the pandemic - a result from, among other reasons, the reduction in transport emissions during isolation. The isolation measures in place during the Covid-19 pandemic allowed telemedicine practices to take place even in countries they were not broadly accepted (Leite et al., 2020). This enabled improvements in air and waste emissions (Sarkis et al., 2020), which uncovers the impacts human activities cause in the environment and confirms Sarkis et al. (2020) preposition of implementing more sustainable modes of consumption.

\section{Other trends for post-pandemic economy}

Other tendencies were also suggested to a post-pandemic economy. More delivery and less in-person shopping, service delivery, online shopping and online payment were presented (Açikgöz and Günay, 2020; Gray, 2020), due to the possibility of assuring social distancing 
during these activities - a behavior people are likely to maintain even after the outbreak eases (Açikgöz and Günay, 2020).

Entrepreneurship and the employment of local businesses are also presented as trends (Liu et al., 2020). Uber drivers could be employed to deliver groceries to vulnerable or highrisk individuals (Gray, 2020), as the demand for Uber runs is not on its normal level during isolation period. As discussed before, the practice of promoting local businesses is a sustainable one, and entrepreneurship allows the achievement of innovative solutions.

\section{DISCUSSIONS}

Content analysis presented impacts, possible points of change and opportunities regarding a post-pandemic period. These results were briefly discussed before and are now deeply discussed.

Supply chain operations were highly affected by Covid-19 outbreak (Lu et al., 2020). Section of content analysis of the paper presented the impacts, as well as opportunities and tendencies identified in the literature for supply chain operations in a post-pandemic period. On one hand, suggestions with a more direct economic approach, regarding companies' operations were presented. Relocation of activities, decentralization from Chinese operations (Liu et al., 2020) and interconnected supply networks to ensure a long-term survival of companies (Ivanov and Dolgui, 2020) are some examples.

On the other hand, supply networks aspects were studied. The work of Ivanov (2020) demonstrated the importance of developing a business network with local partners, to reduce the risk of disruption in the supply chains due to external conditions (such as Covid-19 outbreak). Maintaining a local business network is also a contribution to sustainability (Vezzoli et al., 2018), and to Circular Economy models. Beuren et al. $(2013$, p. 228) had already stated that "[...] the global market faces continual changes, and the PSS [Product-Service System] is one pathway to accommodate those changes through a strong link among the stakeholders".

This link among stakeholders proposed by PSS is a Circular Economy practice, and it is also aligned with the $17^{\text {th }}$ Sustainable Development Goal, "Partnership for the Goals" (Schroeder et al., 2019). The contributions from the proposition of using 3D printing technologies to produce spear parts, reducing products' premature obsolescence and generating economic opportunities to small businesses are twofold. Besides fulfilling social and environmental sustainability, the practice is also aligned with Product-Service Systems, Circular Economy and the Sustainable Development Goals (SDGs).

The implementation of the Sustainable Development Goals and the Circular Economy are reflected in advantages of economic, social and environmental attributes, as well as in sustainable development (Pla-Julián and Guevara, 2019; Priyadarshini and Abhilash, 2020). The shared economy or the Product-Service System stand out for offering more sustainable consumption options and contributing to achieving the goals of the SDGs, especially in emerging or developing economies (Retamal, 2019).

Results showed that tele-solutions for healthcare and other topics of interest are a step forward into the accomplishment of more sustainable modes of production and consumption, for their indirect contributions to decrease in waste and air emissions. In addition to that, studies (e.g. Alcayaga et al., 2019; Chen et al., 2019) have been showing the contribution of IoT, Big Data and other information management technologies to Circular Economy and Product-Service Systems. Alcayaga et al. (2019), for example, discussed the integration of Product-Service Systems, Circular Economy and Smart Products (a fusion of digital and physical worlds with support from information management technologies).

\section{CONCLUSIONS}

The impacts caused by Covid-19 outbreak in global economy have been discussed in this paper. In order to answer the research question "What are the business tendencies to the 
post-outbreak period?", this paper had the goal of conducting a systematic literature review to identify opportunities to minimize Covid-19 impacts on businesses.

This literature review was conducted in four phases, structured according to the PRISMA method. The results of the bibliometric analysis, highlight the high rate of publications on Covid-19, demonstrating the relevance and urgency of the development of research in this area. The content analysis showed the trends for the post-Pandemic economy, which represent guidelines and opportunities to ensure the resilience of business proposals.

Product-Service Systems and Circular Economy were identified as business opportunities for short-term businesses in a post-pandemic period. This work discussed the major suggestions, their contributions and benefits to the provider, the society and the environment, highlighting their alignment with the results of this paper.

This article contributes to the identification of perspectives to react in a resilient way in the post-Pandemic period of Covid-19, in order to guarantee the permanence and competitiveness of companies in the market. However, research limitations can be pointed out. Despite the intention to capture as many articles as possible, not all contributions were considered, since the bibliographic search was limited to articles, published in English, between 2015 and 2020.

Future research may include, but not be limited to, the perspectives presented in the following. It is suggested the development of studies that aim at minimizing the impacts of Covid-19 through the interrelationship with concepts such as circular economy, ProductService Systems, Sustainable Development Goals and Reverse Logistics, considering their contributions to the post-pandemic period in the environmental, societal and economic spheres. There is also an opportunity to develop empirical research, capable of quantifying the benefits of these interrelations and the contribution of the trends identified in this research to ensure the resilience of the economy.

\section{REFERENCES}

Açikgöz, Ö. and Günay, A. (2020), "The early impact of the Covid-19 pandemic on the global and Turkish economy", Turkish Journal of Medical Sciences, Vol. 50, pp. 520-6. http://dx.doi.org/10.3906/sag-20046.

Alcayaga, A., Wiener, M. and Hansen, E.G. (2019), "Towards a framework of smart-circular systems: An integrative literature review", Journal of Cleaner Production, Vol. 221, pp. 622-34. http://dx.doi.org/10.1016/j.jclepro.2019.02.085.

Annarelli, A., Battistella, C. and Nonino, F. (2016), "Product service system: a conceptual framework from a systematic review", Journal of Cleaner Production, Vol. 139, pp. 1011-32. http://dx.doi.org/10.1016/j.jclepro.2016.08.061.

Armani, A.M., Hurt, D.E., Hwang, D. et al. (2020), "Low-tech solutions for the COVID-19 supply chain crisis", Nature Reviews. Materials, Vol. 5, pp. 403-6. http://dx.doi.org/10.1038/s41578-020-0205-1.

Benachio, G.L.F., Freitas, M.C.D. and Tavares, S.F. (2020), "Circular economy in the construction industry: a systematic literature review", Journal of Cleaner Production, Vol. 260, pp. 121046. http://dx.doi.org/10.1016/j.jclepro.2020.121046.

Beuren, F.H., Gomes Ferreira, M.G. and Cauchick Miguel, P.A. (2013), "Product-service systems: a literature review on integrated products and services", Journal of Cleaner Production, Vol. 47, pp. 22231. http://dx.doi.org/10.1016/j.jclepro.2012.12.028.

Calignano, F., Manfredi, D., Ambrosio, E.P. et al. (2017), "Overview on additive manufacturing technologies", Proceedings of the IEEE, Vol. 105, No. 4, pp. 593-612. http://dx.doi.org/10.1109/JPROC.2016.2625098.

Celesti, A., Ruggeri, A., Fazio, M. et al. (2020), "Blockchain-based healthcare workflow for tele-medical laboratory in Federated Hospital IoT Clouds", Sensors (Basel), Vol. 20, No. 9, pp. 2590. http://dx.doi.org/10.3390/s20092590.

Chadegani, A.A., Salehi, H., Yunus, M. et al. (2013), "A comparison between two main academic literature collections: web of science and scopus databases", Asian Social Science, Vol. 9, No. 5, pp. 18-26. http://dx.doi.org/10.5539/ass.v9n5p18. 
Chakraborty, I. and Maity, P. (2020), "COVID-19 outbreak: migration, effects on society, global environment and prevention", The Science of the Total Environment, Vol. 728, pp. 138882. http://dx.doi.org/10.1016/j.scitotenv.2020.138882.

Chen, Z., Ming, X., Zhang, X. et al. (2019), "A rough-fuzzy DEMATEL-ANP method for evaluating sustainable value requirement of product service system", Journal of Cleaner Production, Vol. 228, pp. 485-508. http://dx.doi.org/10.1016/j.jclepro.2019.04.145.

Cox, J.L. and Koepsell, S.A. (2020) "3D-Printing to Address COVID-19 Testing Supply Shortages," Laboratory Medicine, Vol. 51, No. 4, pp. e45-6. http://dx.doi.org/10.1093/labmed/lmaa031.

Ellen MacArthur Foundation (2017). "What is a circular economy? A framework for an economy that is restorative and regenerative by design", Available at: https://www.ellenmacarthurfoundation.org/circular-economy/concept (accessed 17 March 2021).

Fernandes, S.D.C., Pigosso, D.C.A., McAloone, T.C. et al. (2020), "Towards product-service system oriented to circular economy: a systematic review of value proposition design approaches", Journal of Cleaner Production, Vol. 257. http://dx.doi.org/10.1016/j.jclepro.2020.120507.

Geissdoerfer, M., Savaget, P., Bocken, N.M.P. et al. (2017), "The circular economy - a new sustainability paradigm", Journal of Cleaner Production, Vol. 143, pp. 757-68. http://dx.doi.org/10.1016/j.jclepro.2016.12.048.

Giudice, A., Barone, S., Muraca, D. et al. (2020), "Can teledentistry improve the monitoring of patients during the covid-19 dissemination? A descriptive pilot study", International Journal of Environmental Research and Public Health, Vol. 17, No. 10, pp. 3399. http://dx.doi.org/10.3390/ijerph17103399.

Gray, R.S. (2020) "Agriculture, transportation, and the COVID-19 crisis," Canadian Journal of Agricultural Economics/Revue canadienne d'agroeconomie, Vol. 68, No. 2, pp. 239-43. http://dx.doi.org/10.1111/cjag.12235.

Guzzo, D., Trevisan, A.H., Echeveste, M. et al. (2019), "Circular innovation framework: Verifying conceptual to practical decisions in sustainability-oriented product-service system cases", Sustainability (Switzerland), Vol. 11, No. 12. http://dx.doi.org/10.3390/su11123248.

Hailu, G. (2020) "Economic thoughts on COVID-19 for Canadian food processors," Canadian Journal of Agricultural Economics/Revue canadienne d'agroeconomie, Vol. 68, No. 2, pp. 163-9. http://dx.doi.org/10.1111/cjag.12241.

Hall, C.M., Scott, D. and Gössling, S. (2020), "Pandemics, transformations and tourism: be careful what you wish for", Tourism Geographies, pp. 577-98. http://dx.doi.org/10.1080/14616688.2020.1759131.

Halstenberg, F.A., Lindow, K. and Stark, R. (2019), "Leveraging circular economy through a methodology for smart service systems engineering", Sustainability (Switzerland), Vol. 11, No. 13, pp. 3517. http://dx.doi.org/10.3390/su11133517.

Hankammer, S., Brenk, S., Fabry, H. et al. (2019), "Towards circular business models: Identifying consumer needs based on the jobs-to-be-done theory", Journal of Cleaner Production, Vol. 231, pp. 341-58. http://dx.doi.org/10.1016/j.jclepro.2019.05.165.

Ivanov, D. (2020), "Predicting the impacts of epidemic outbreaks on global supply chains: a simulationbased analysis on the coronavirus outbreak (COVID-19/SARS-CoV-2) case", Transportation Research Part E, Logistics and Transportation Review, Vol. 136, pp. 101922. http://dx.doi.org/10.1016/j.tre.2020.101922.

Ivanov, D. and Dolgui, A. (2020), "Viability of intertwined supply networks: extending the supply chain resilience angles towards survivability. A position paper motivated by COVID-19 outbreak", International Journal of Production Research, Vol. 58, No. 10, pp. 2904-15. http://dx.doi.org/10.1080/00207543.2020.1750727.

lyengar, K., Bahl, S., Raju, V. et al. (2020), "Challenges and solutions in meeting up the urgent requirement of ventilators for COVID-19 patients", Diabetes \& Metabolic Syndrome, Vol. 14, No. 4, pp. 499-501. http://dx.doi.org/10.1016/j.dsx.2020.04.048.

Jia, F., Yin, S., Chen, L. et al. (2020), "The circular economy in the textile and apparel industry: a systematic literature review", Journal of Cleaner Production, Vol. 259, pp. 120728. http://dx.doi.org/10.1016/j.jclepro.2020.120728.

Khan, S.A.R., Yu, Z., Golpira, H. et al. (2021), "A state-of-the-art review and meta-analysis on sustainable supply chain management: Future research directions", Journal of Cleaner Production, Vol. 278, pp. 123357. http://dx.doi.org/10.1016/j.jclepro.2020.123357. 
Király, O., Potenza, M.N., Stein, D.J. et al. (2020), "Preventing problematic internet use during the COVID19 pandemic: Consensus guidance", Comprehensive Psychiatry, Vol. 100, pp. 1-4. http://dx.doi.org/10.1016/j.comppsych.2020.152180.

Kjaer, L.L., Pigosso, D.C.A., Niero, M. et al. (2019), "Product/service-systems for a circular economy: the route to decoupling economic growth from resource consumption", Journal of Industrial Ecology, Vol. 23, No. 1, pp. 22-35. http://dx.doi.org/10.1111/jiec.12747.

Laing, T. (2020) "The economic impact of the Coronavirus 2019 (Covid-2019): implications for the mining industry," The Extractive Industries and Society, Vol. 7, No. 2, pp. 580-82. http://dx.doi.org/10.1016/j.exis.2020.04.003.

Leite, H., Hodgkinson, I.R. and Gruber, T. (2020) “New development: 'Healing at a distance'-telemedicine and COVID-19," Public Money and Management, Vol. 40, No. 6, pp. 483-85. http://dx.doi.org/10.1080/09540962.2020.1748855.

Li, L., Li, Q., Huang, L. et al. (2020a), "Air quality changes during the COVID-19 lockdown over the Yangtze River Delta Region: an insight into the impact of human activity pattern changes on air pollution variation", The Science of the Total Environment, Vol. 732, pp. 139282. http://dx.doi.org/10.1016/j.scitotenv.2020.139282.

Li, L., Li, R., Wu, Z. et al. (2020b), "Therapeutic strategies for critically ill patients with COVID-19", Annals of Intensive Care, Vol. 10, No. 45. http://dx.doi.org/10.1186/s13613-020-00661-z.

Lin, Y., Wang, Y. and Kung, L.A. (2012), "Influences of cross-functional collaboration and knowledge creation on technology commercialization: Evidence from high-tech industries", Industrial Marketing Management, Vol. 49, pp. 128-38. http://dx.doi.org/10.1016/j.indmarman.2015.04.002.

Liu, Y., Lee, J. M. and Lee, C. (2020) "The challenges and opportunities of a global health crisis: the management and business implications of COVID-19 from an Asian perspective," Asian Business \& Management, Vol. 29, pp. 277-97. http://dx.doi.org/10.1057/s41291-020-00119-x.

Lu, Y., Wu, J., Peng, J. et al. (2020), "The perceived impact of the Covid-19 epidemic: evidence from a sample of 4807 SMEs in Sichuan Province, China", Environmental Hazards, Vol. 7891, pp. 1-18. http://dx.doi.org/10.1080/17477891.2020.1763902.

Moher, D., Liberati, A., Tetzlaff, J. et al. (2009), "Preferred Reporting items for systematic reviews and meta-analyses: the PRISMA Statement (Reprinted from Annals of Internal Medicine)", Physical Therapy, Vol. 89, No. 9, pp. 873-80. http://dx.doi.org/10.1371/journal.pmed.1000097.

Mont, O.K. (2002), "Clarifying the concept of product-service system", Journal of Cleaner Production, Vol. 10, pp. 237-45. http://dx.doi.org/10.1109/ACIIDS.2009.18.

Nova-Reyes, A., Muñoz-Leiva, F. and Luque-Martínez, T. (2020), "The tipping point in the status of socially responsible consumer behavior research? A bibliometric analysis", Sustainability (Switzerland), Vol. 12, No. 8, pp. 3141. http://dx.doi.org/10.3390/SU12083141.

Pieroni, M.P.P., McAloone, T.C. and Pigosso, D.C.A. (2019), "Configuring new business models for circular economy through product-service systems", Sustainability (Switzerland), Vol. 11, No. 13, pp. 3727. http://dx.doi.org/10.3390/su11133727.

Pla-Julián, I. and Guevara, S. (2019), "Is circular economy the key to transitioning towards sustainable development? Challenges from the perspective of care ethics", Futures, Vol. 105, pp. 67-77. http://dx.doi.org/10.1016/j.futures.2018.09.001.

Prideaux, B., Thompson, M. and Pabel, A. (2020), "Lessons from COVID-19 can prepare global tourism for the economic transformation needed to combat climate change", Tourism Geographies. Routledge, Vol. 22, No. 3, pp. 667-78. http://dx.doi.org/10.1080/14616688.2020.1762117.

Priyadarshini, P. and Abhilash, P.C. (2020), "Circular economy practices within energy and waste management sectors of India: a meta-analysis", Bioresource Technology, Vol. 304, pp. 123018. http://dx.doi.org/10.1016/j.biortech.2020.123018.

Ramakrishna, R., Zadeh, G., Sheehan, J.P. et al. (2020), "Inpatient and outpatient case prioritization for patients with neuro-oncologic disease amid the COVID-19 pandemic: general guidance for neurooncology practitioners from the AANS/CNS Tumor Section and Society for Neuro-Oncology", Journal of Neuro-Oncology, Vol. 147, No. 3, pp. 525-9. http://dx.doi.org/10.1007/s11060-020-03488-7.

Retamal, M. (2019), "Collaborative consumption practices in Southeast Asian cities: prospects for growth and sustainability", Journal of Cleaner Production, Vol. 222, pp. 143-52. http://dx.doi.org/10.1016/j.jclepro.2019.02.267. 
Rowan, N.J. and Laffey, J.G. (2020), "Challenges and solutions for addressing critical shortage of supply chain for personal and protective equipment (PPE) arising from Coronavirus disease (COVID19) pandemic - Case study from the Republic of Ireland", The Science of the Total Environment, Vol. 725, pp. 138532. http://dx.doi.org/10.1016/j.scitotenv.2020.138532.

Ryan, B.J., Coppola, D., Canyon, D.V. et al. (2020), "COVID-19 community stabilization and sustainability framework: an integration of the maslow hierarchy of needs and social determinants of health", Disaster Medicine and Public Health Preparedness, Vol. 14, No. 5, pp. 1-7. http://dx.doi.org/10.1017/dmp.2020.109.

Sarkis, J., Cohen, M.J., Dewick, P. et al. (2020), "A brave new world: lessons from the COVID-19 pandemic for transitioning to sustainable supply and production", Resources, Conservation and Recycling, Vol. 159, pp. 104894. http://dx.doi.org/10.1016/j.resconrec.2020.104894.

Schröder, P., Bengtsson, M., Cohen, M. et al. (2019), "Degrowth within - Aligning circular economy and strong sustainability narratives", Resources, Conservation and Recycling, Vol. 146, pp. 190-1. http://dx.doi.org/10.1016/j.resconrec.2019.03.038.

Schroeder, P., Anggraeni, K. and Weber, U. (2019), "The Relevance of Circular Economy Practices to the Sustainable Development Goals", Journal of Industrial Ecology, Vol. 23, No. 1, pp. 77-95. http://dx.doi.org/10.1111/jiec.12732.

Secco, C., da Luz, L.M., Pinheiro, E. et al. (2020), "Circular economy in the pig farming chain: Proposing a model for measurement", Journal of Cleaner Production, Vol. 260, pp. 121003. http://dx.doi.org/10.1016/j.jclepro.2020.121003.

Shokrani, A., Loukaides, E.G., Elias, E. et al. (2020), "Exploration of alternative supply chains and distributed manufacturing in response to COVID-19; a case study of medical face shields", Materials \& Design, Vol. 192, pp. 108749. http://dx.doi.org/10.1016/j.matdes.2020.108749.

Smith, A.C., Thomas, E., Snoswell, C.L. et al. (2020), "Telehealth for global emergencies: Implications for coronavirus disease 2019 (COVID-19)", Journal of Telemedicine and Telecare, Vol. 26, No. 5. http://dx.doi.org/10.1177/1357633X20916567.

Thornton, J. (2020), "UN adopts new global health targets to supersede the millennium goals", BMJ (Clinical Research Ed.), Vol. 351, pp. 1. http://dx.doi.org/10.1136/bmj.h5177.

Tokarz, B., Tokarz, B., Fagundes, A.B. et al. (2020), "Product-service systems: a literature review on assisting development", International Journal of Advanced Engineering Research and Science, Vol. 6495, No. 6

Tukker, A. (2015), "Product services for a resource-efficient and circular economy - a review", Journal of Cleaner Production, Vol. 97, pp. 76-91. http://dx.doi.org/10.1016/j.jclepro.2013.11.049.

van Eck, N.J. and Waltman, L. (2014). "Visualizing bibliometric networks", in Ding, Y., Rousseau, R. and Wolfram, D. (Eds.), Measuring Scholarly Impact, Springer, Cham. https://doi.org/10.1007/978-3-31910377-8_13.

Vezzoli, C., Ceschin, F., Osanjo, L. et al. (2018). Designing Sustainable Energy for All. Sustainable ProductService System Design Applied to Distributed Renewable Energy, Designing Sustainable Energy for All, Springer, USA. http://dx.doi.org/10.1007/978-3-319-70223-0.

Wong, D. (2018), VOSviewer, Technical Services Quarterly, Vol. 35, No. 2, pp. 219-20. http://dx.doi.org/10.1080/07317131.2018.1425352.

World Health Organization (2021). WHO: People living longer and healthier lives but COVID-19 threatens to throw progress off track. Available at: https://www.who.int/news/item/13-05-2020-people-livinglonger-and-healthier-lives-but-covid-19-threatens-to-throw-progress-off-track?utm_campaign=whopeople-living-longer-and-healthier-lives-but-covid-19-threatens-to-throw-progress-off-track-worldhealth-organization\&utm_medium=rss\&utm_source=rss (accessed 17 March 2021).

World Tourism Organization - UNWTO (2020), Covid-19: putting people first. Available at: https://www.unwto.org/tourism-covid-19 (accessed 17 March 2021).

Yang, X., Moore, P., Pu, J.S. et al. (2009), "A practical methodology for realizing product service systems for consumer products", Computers \& Industrial Engineering, Vol. 56, No. 1, pp. 224-35. http://dx.doi.org/10.1016/j.cie.2008.05.008.

Yu, M., Zhang, W. and Meier, H. (2008), "Modularization based design for innovative product-related industrial service," in Proceedings of 2008 IEEE International Conference on Service Operations and 
Logistics, and Informatics, IEEE/SOLI, 2008, IEEE, USA, pp. 48-53. http://dx.doi.org/10.1109/SOLI.2008.4686360.

Yu, Z. and Khan, R.S.A. (2021), "Evolutionary game analysis of green agricultural product supply chain financing system: COVID-19 pandemic", International Journal of Logistics Research and Applications, pp. 1-21. http://dx.doi.org/10.1080/13675567.2021.1879752.

Zambrano-Monserrate, M.A., Ruano, M.A. and Sanchez-Alcalde, L. (2020), "Indirect effects of COVID-19 on the environment", The Science of the Total Environment, Vol. 728, pp. 138813. http://dx.doi.org/10.1016/j.scitotenv.2020.138813.

Zhang, Y., Koopmans, M., Andersen, K. et al. (2020a), "The novel coronavirus outbreak: what we know and what we don't", Cell, Vol. 180, No. 6, pp. 1034-6. http://dx.doi.org/10.1016/j.cell.2020.02.027.

Zhang, Z., Xu, D., Ostrosi, E. et al. (2020b), "Optimization of the product-service system configuration based on a multilayer network", Sustainability (Switzerland), Vol. 12, No. 2, pp. 746. http://dx.doi.org/10.3390/su12020746.

Author contributions: All the authors contributed equally to this paper. 